\title{
Pengaruh Gaya Kepemimpinan, Budaya Organisasi dan Motivasi Kerja Terhadap Kinerja Melalui Kepuasan Kerja pada Pegawai Badan Pengelolaan Keuangan dan Aset Daerah Kota Tanjungpinang
}

\author{
Muhammad Fais Fahmi \\ Fakultas Ekonomi, Universitas Batam \\ Cablullah Wibisono \\ Fakultas Ekonomi, Universitas Batam \\ Bambang Satriawan \\ Fakultas Ekonomi, Universitas Batam \\ Email:faisfahmi1995@gmail.com
}

\begin{abstract}
Abstrak
Penelitian ini bertujuan untuk mengetahui pengaruh gaya kepemimpinan, budaya organisasi, dan motivasi kerja terhadap kinerja karyawan melalui kepuasan kerja. Responden penelitian ini adalah seluruh pegawai di lingkungan Kantor Badan Pengelolaan Keuangan dan Aset Daerah Kota Tanjungpinang $(\mathrm{N}=81)$. Pengumpulan data dilakukan pada Maret 2021 melalui penyebaran angket yang berisikan 5 skala penelitian yaitu skala gaya kepemimpinan, skala budaya organisasi, skala motivasi kerja, skala kepuasan kerja, dan skala kinerja. Teknik analisis data yang digunakan ialah SEM-PLS. Hasil penelitian menunjukkan bahwa gaya kepemimpingan, budaya organisasi, dan motivasi kerja memiliki efek secara langsung terhadap kepuasan kerja. Selain itu, gaya kepemimpinan, motivasi kerja dan kepuasan kerja memiliki efek secara langsung terhadap kinerja karyawan. Akan tetapi, budaya organisasi tidak memiliki efek secara langsung terhadap kinerja. Hasil penelitian juga menunjukkan bahwa gaya kepemimpinan, budaya organisasi dan motivasi kerja memiliki efek secara tidak langsung terhadap kinerja melalui kepuasan kerja.
\end{abstract}

Kata Kunci: Gaya Kepemimpinan, Budaya Organisasi, Motivasi Kerja, Kepuasan Kerja, Kinerja

\section{Pendahuluan}

Sebagaimana kita ketahui bahwa Pengelolaan Keuangan Daerah adalah keseluruhan kegiatan yang meliputi perencanaan, penganggaran, pelaksanaan, penatausahaan, pelaporan, pertanggungjawaban, dan pengawasan Keuangan Daerah. Keuangan Daerah adalah semua hak dan kewajiban Daerah dalam rangka penyelenggaraan Pemerintahan Daerah yang dapat dinilai dengan uang serta segala bentuk kekayaan yang dapat dijadikan milik Daerah berhubung dengan hak dan kewajiban Daerah tersebut. Keuangan Daerah selain diatur dengan Peraturan Pemerintah juga mengikuti Peraturan Menteri dan keuangan daerah juga mengikuti UndangUndang Anggaran Pendapatan dan Belanja Negara yang ditetapkan setiap tahun, dan Anggaran Pendapatan dan Belanja Daerah masing-masing daerah yang disinkronkan dan dikelola secara sistematis.

Kota Tanjungpinang sudah enam kali berturut-turut mendapatkan predikat Wajar Tanpa Pengecualian (WTP) oleh Badan Penyelidik Keuangan (BPK), itu semua tidak terlepas 
dari keberhasilan BPKAD dalam mengelola laporan keuangan setiap tahunnya. Upaya perbaikan dan penyempurnaan dalam pengelolaan keuangan terus dilakukan untuk mempertahankan predikat tersebut, semua itu tidak terlepas dari kinerja pegawai ASN dan Non ASN yang berada di lingkungan BPKAD. Banyak faktor yang mempunyai pengaruh terhadap kinerja pegawai BPKAD, namun dalam penelitian ini hanya dibatasi pada Kepemimpinan, Budaya Organisasi, Motivasi dan Kepuasan Kerja.

Tabel 1. Target Realisasi Anggaran di BPKAD

\begin{tabular}{|c|c|c|c|}
\hline Tahun & Target & Realisasi & Persentase \\
\hline 2018 & 17.938 .220 .121 & 14.368 .724 .508 & $80 \%$ \\
\hline 2019 & 23.667 .112 .677 & 18.962 .349 .092 & $80 \%$ \\
\hline 2020 & 16.854 .541 .823 & 11.207 .744 .166 & $66 \%$ \\
\hline
\end{tabular}

(Sumber: Bagian Program Badan Pengelolaan Keuangan dan Aset Daerah Kota Tanjungpinang)

Dari Tabel 1. dapat di lihat bahwa selama tiga tahun dari 2018 hingga 2020 target realisasi anggaran pada BPKAD belum terserap dengan sempurna, bahkan pada tahun 2020 penurunan drastis dari realisasi terhadap target yang telah ditetapkan. Ini merupakan suatu yang harus di perbaiki agar ke depannya BPKAD dapat lebih meningkatkan kinerjanya dan realisasi anggaran yang telah ditetapkan dapat dimaksimalkan penggunaannya. Proses pelaksanaan tugas pokok dan fungsi dari BPKAD, bukan hanya membutuhkan program kerja yang baik dan sesuai dengan visi misi organisasi, tetapi dibutuhkan juga sumber daya manusia yang kompeten dalam mengerjakan tugas-tugas pencapaian tujuan kinerja pegawai pada organisasi.

Beberapa penelitian terdahulu menemukan bahwa gaya kepemimpinan, budaya organisasi, motivasi kerja dan kepuasan kerja dapat mempengaruhi kinerja pegawai (Brury, 2016; Andayani \& Tirtayasa, 2019; Wahyuni, 2015; Marimin, 2011; Adinata, 2016; Prasada, 2020; Hamidi, 2020; Effendy \& Fitria, 2017). Tingkat pengaruh kepemimpinan, motivasi, dan budaya organisasi terhadap kinerja karyawan ada yang ditemukan sebesar $20.34 \%$ (Marimin, 2011), hingga 78\% (Adinata, 2016). Selain itu, Prasada (2020) menemukan bahwa gaya kepemimpinan dan budaya organisasi secara simultan memberikan pengaruh sebesar $61.7 \%$ terhadap kinerja karyawan, sedangkan Hamidi (2020) menemukan bahwa gaya kepemimpinan dan motivasi kerja secara simultan memberikan pengaruh sebesar $87.5 \%$ terhadap kinerja karyawan. Berdasarkan uraian tersebut, penulis tertarik untuk mengetahui pengaruh gaya kepemimpinan, budaya organisasi dan motivasi kerja terhadap kinerja pegawai melalui kepuasan kerja pada pegawai badan pengelolaan keuangan dan aset daerah kota Tanjungpinang.

\section{Landasan Teori dan Pengembangan Hipotesis}

\section{Gaya Kepemimpinan}

Kepemimpinan menurut etimologi, berasal dari kata dasar pimpin atau lead yang diartikan sebagai bombing atau tuntun (Hasibuan, 2007). Marimin (2011) menyebutkan bahwa gaya kepemimpinan ialah pola perilaku yang konsisten oleh seorang pemimpin saat mempengaruhi orang lain. Menurut Asnawi (2011) kepemimpinan merupakan kemampuan untuk dapat mempengaruhi dan mengatur perilaku sendiri, seseorang, atau sekelompok orang untuk dapat mencapai tujuan tertentu. Gaya kepemimpinan ialah suatu aturan yang mengatur 
perilaku seseorang dalam mempengaruhi orang lain (Thoha, 2010). Berdasarkan semua pengertian yang telah dikemukakan para ahli di atas, dapat disimpulkan bahwa kepemimpinan adalah proses dan perilaku seorang pemimpin dalam mempengaruhi perilaku dan mendayagunakan bawahan agar mau bekerja sama dalam melaksanakan tugas dan tanggung jawab untuk mencapai tujuan perusahaan atau organisasi. Heidjrachman dan Husnan (Basna, 2016) menyebutkan bahwa terdapat tiga dimensi dari gaya kepemimpinan, diantaranya ialah sebagai berikut:

1. Gaya kepemimpinan otoriter, yang cenderung memiliki wewenang mutlak terpusat pada pimpinan, keputusan selalu dibuat oleh pimpinan, serta tidak adanya kesempatan bagi bawahan untuk memberikan saran.

2. Gaya kepemimpinan delegatif, yang cenderung melimpahkan wewenang lebih banyak kepada bawahan, keputusan lebih banyak dibuat oleh para bawahan dan bawahan bebas menyampaikan saran dan pendapat.

3. Gaya kepemimpinan partisipatif, dimana pemimpin cenderung tidak memiliki wewenang yang mutlak, keputusan dibuat bersama antara pimpinan dan bawahan dan terdapat banyak kesempatan bagi bawahan untuk menyampaikan saran dan pendapat.

\section{Budaya Organisasi}

Kata budaya adalah suatu perkembangan dari bahasa sansekerta 'budhayah' yaitu bentuk jamak dari buddhi atau akal, dan kata majemuk budi daya, yang berarti daya dari budi, dengan kata lain "budaya adalah daya dari budi yang berupa cipta, karsa dan rasa, sedangkan kebudayaan merupakan pengembangan dari budaya, yaitu hasil dari cipta, karsa dan rasa tersebut Widagho, D (2010). Menurut Schein (2010) budaya organisasi ialah suatu pola asumsi dasar bersama yang dipelajari kelompok tertentu untuk mengatasi masalah adaptasi eksternal dan integrasi internal, diajarkan kepada anggota baru sebagai cara yang benar untuk memahami, berfikir dan merasa masalah tersebut. Oleh karena itu budaya organisasi diajarkan/diwariskan kepada anggota anggota baru sebagai cara yang tepat memahami, memikirkan dan merasakan terkait dengan masalah-masalah tersebut. Menurut Quinn dan Cameron (Susilo, 2018) budaya organisasi memiliki 4 dimensi yaitu sebagai berikut:

1. Clan culture, yang cenderung menitikberatkan pada hubungan kekeluargaan.

2. Adhocracy culture, yang cenderung lebih mengalir dan tidak banyak membatasi terkait struktur organisasi.

3. Market culture adalah jenis budaya organisasi yang lebih mengutamakan kompetensi, sehingga cenderung terdapat persaingan yang kuat.

4. Hierarchy culture merupakan budaya organisasi yang lebih mementingkan struktur yang rapi, sehingga proses cenderung diatur secara baku dan sistematis.

\section{Motivasi Kerja}

Motivasi merupakan faktor penentu perilaku orang-orang untuk bekerja, yang mana perilaku merupakan cerminan sederhana dari motivasi kerja, Sutrisno (2014). Oleh karena itu, saat pegawai tidak memiliki keahlian untuk bekerja, maka motivasi tersebut tidak akan meningkatkan prestasi kerja. Motivasi kerja menurut Danim (2014) ialah dorongan dari dalam diri individu untuk secara sadar melakukan pekerjaan yang sedang dihadapi. Rivai (2011) mengemukakan bahwa motivasi ialah serangkaian dari sikap dan norma yang mempengaruhi seseorang untuk mencapai tujuan atau hal-hal spesifik lainnya. Selain itu, Bangun (2012) menyebutkan bahwa motivasi merupakan hasrat dalam diri seseorang yang menyebabkan 
orang tersebut melakukan suatu tindakan. Menurut Emil dan Albetris (2018) motivasi kerja terdiri atas 3 aspek yaitu intensitas, arah, dan ketekunan.

\section{Kinerja}

Wibowo (2013) mengemukakan bahwa kinerja adalah tentang melakukan pekerjaan dan hasil yang dicapai dari pekerjaan tersebut. Kinerja juga mengandung makna tentang apa yang dikerjakan dan bagaimana cara mengerjakannya. Sedarmayanti (2013) menyatakan bahwa kinerja adalah suatu sistem yang dapat digunakan untuk menilai sejauh mana pegawai secara keseluruhan telah melaksanakan pekerjaan, atau dapat dikatakan bahwa kinerja adalah akumulasi dari hasil kerja secara keseluruhan. Menurut Hersey dan Hard (Manguprawira, 2015) kinerja merupakan hasil dari motivasi dan kemampuan yang dimiliki pegawai dalam bekerja. Saat seseorang berusaha untuk menyelesaikan tuntutan pekerjaan atau tugas, kemampuan dan keterampilan yang dimiliki harus disertai dengan pemahaman yang jelas mengenai hal-hal yang akan dikerjakan dan bagaimana cara mengerjakan pekerjaan tersebut. Menurut Prawirosentono (2012) kinerja pegawai terdiri atas 2 aspek, yaitu sebagai berikut:

1. Penilaian umum, yaitu penilaian terhadap kinerja pegawai yang meliputi jumlah pekerjaan, kualitas pekerjaan, pengetahuan atas tugas, kerjasama, tanggung jawab, sikap dan inisiatif.

2. Penilaian keterampilan, yang termasuk didalamnya ketrampilan teknis, kemampuan mengambil keputusan, kepemimpinan, administrasi dan kreatifitas.

\section{Kepuasan Kerja}

Secara sederhana kepuasan kerja dapat diartikan sebagai besarnya rasa suka pegawai terhadap pekerjaannya dan ketidakpuasan kerja menunjukkan besarnya rasa tidak suka pegawai terhadap pekerjaan. Kepuasan kerja merupakan salah satu aspek psikologis yang ikut mempengaruhi perilaku pegawai dalam melakukan aktivitasnya. Kepuasan kerja sangat penting bagi pegawai karena kepuasan kerja yang dirasakan oleh pegawai akan berdampak terhadap pekerjaan dan kualitas kerjanya. Pegawai yang merasa senang dan puas dengan pekerjaannya tentu ia akan melaksanakan tugasnya dengan sebaik-baiknya untuk mendapatkan kepuasan yang sama atau lebih sehingga akan berdampak positif terhadap hasil kerjanya. Sebaliknya, apabila pegawai tidak senang atau tidak puas maka ia akan menghasilkan pekerjaannya, sehingga berdampak negatif terhadap hasil kerjanya (Annisa, 2013). Menurut Khasanah (2013) terdapat beberapa aspek kepuasan kerja yaitu sebagai berikut:

1. Upah, kepuasan kerja merupakan fungsi dari jumlah absolut dari gaji yang diterima, derajat sejauh mana gaji memenuhi harapan-harapan tenaga kerja, dan bagaimana gaji diberikan.

2. Pekerjaan, yaitu sejauh mana pekerjaan dapat menjadi suatu hal yang menyenangkan dan berharga untuk kehidupan seseorang.

3. Promosi, yaitu sejauh mana seseorang merasa puas karena memiliki kesempatan mengembangkan diri dan memperluas pengetahuan dengan terbukanya kesempatan untuk kenaikan jabatan serta tanggung jawab yang diberikan.

4. Atasan, yaitu sejauh mana terdapat supervisor yang menyediakan bantuan teknis dan perilaku dukungan, serta dapat menjalin hubungan fungsional dan hubungan keseluruhan yang positif. 


\section{Hipotesis}

Adapun hipotesis-hipotesis yang dapat dikemukan adalah sebagai berikut :

$\boldsymbol{H}_{1}$ : Ada pengaruh Gaya Kepemimpinan terhadap Kepuasan Kerja pegawai di Badan Pengelolaan Keuangan dan Aset Daerah Kota Tanjungpinang

$\boldsymbol{H}_{2}$ : Ada pengaruh Budaya Organisasi terhadap Kepuasan Kerja pegawai di Badan Pengelolaan Keuangan dan Aset Daerah Kota Tanjungpinang

$\boldsymbol{H}_{3}$ : Ada pengaruh Motivasi Kerja terhadap Kepuasan Kerja pegawai di Badan Pengelolaan Keuangan dan Aset Daerah Kota Tanjungpinang

$\boldsymbol{H}_{4}$ : Ada pengaruh Kepuasan Kerja terhadap Kinerja pegawai di Badan Pengelolaan Keuangan dan Aset Daerah Kota Tanjungpinang

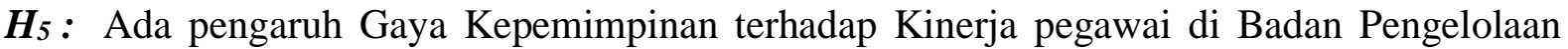
Keuangan dan Aset Daerah Kota Tanjungpinang

H6 $_{6}$ : Ada pengaruh Budaya Organisasi terhadap Kinerja pegawai di Badan Pengelolaan Keuangan dan Aset Daerah Kota Tanjungpinang

$\boldsymbol{H}_{7}$ : Ada pengaruh Motivasi Kerja terhadap Kinerja pegawai di Badan Pengelolaan Keuangan dan Aset Daerah Kota Tanjungpinang

Berdasarkan rumusan hipotesis tersebut, maka diperoleh model konseptual penelitian yaitu sebagai berikut :

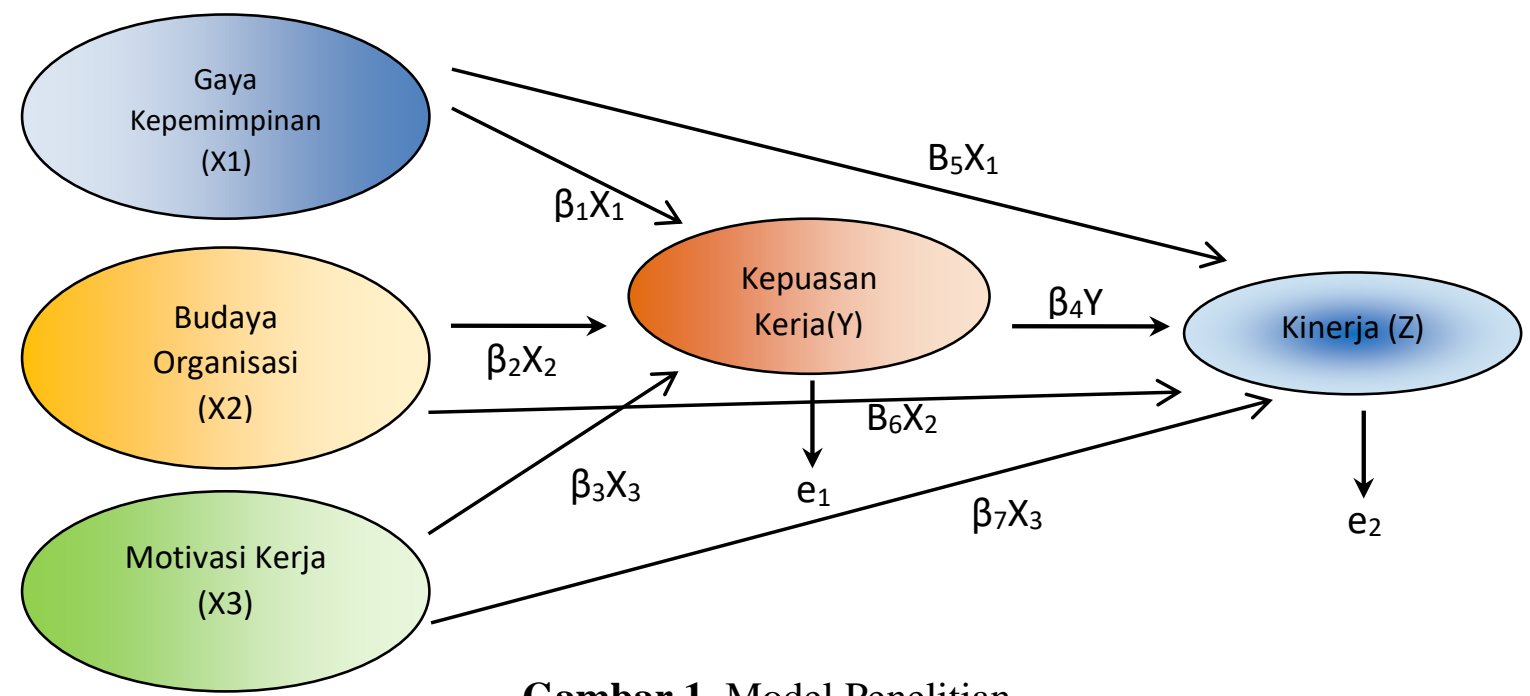

Gambar 1. Model Penelitian

\section{Metode Penelitian}

Penelitian ini menggunakan pendekatan kuantitatif untuk mengukur pengaruh antar variabel eksogen yaitu Gaya Kepemimpinan (X1), Budaya Organisasi (X2), Motivasi Kerja (X3), terhadap Variabel Intervening yaitu Kepuasan Kerja (X4) dan terhadap variabel endogen yaitu Kinerja (Y). Pemilihan Responden penelitian dilakukan secara purposive sampling yaitu teknik pengambilan sampel dengan kriteria tertentu. Responden dalam penelitian ini adalah seluruh pegawai di lingkungan Kantor Badan Pengelolaan Keuangan dan Aset Daerah Kota Tanjungpinang $(\mathrm{N}=81)$.

Pengumpulan data penelitian ini dilakukan pada bulan Maret 2021 dengan menyebarkan angket penelitian. Pengumpulan data dilakukan menggunakan skala Likert yang telah melalui proses uji reliabilitas dan validitas. Peneliti menggunakan 5 skala penelitian, yaitu 
skala gaya kepemimpinan (Handoko dan Reksohadiprodjo, 1997), Organizational Culture Assesment Instrument yang diadaptasi oleh Susilo (2018), skala motivasi kerja (Kaihatu, 2010), skala kepuasan kerja (Kartika \& Kaihatu, 2010), skala kinerja (Yuliana, 2013). Metode analisis data penelitian yang digunakan ialah SEM (Struktural Equation Modelling) melalui aplikasi PLS (Partial Least Square) versi 3.0.

\section{Pembahasan}

Peneliti melakukan analisis model pengukuran (outer model) untuk mengevaluasi variabel konstruk yang diteliti, validitas (ketepatan) dan reliabilitas (kehandalan) dari suatu variabel. Analisis konsistensi internal adalah bentuk reliabilitas yang digunakan untuk menilai konsistensi hasil lintas item pada suatu tes yang sama. Menurut Hair, Hult, Ringle, dan Sarstedt (2014), pengujian konsistensi internal menggunakan nilai reliabilitas komposit dengan kriteria suatu variabel dikatakan reliabel jika nilai reliabilitas komposit >0.60. Selain itu, perlu dilakukan validitas konvergen dan diskriminan. Validitas konvergen digunakan untuk melihat sejauh mana sebuah pengukuran berkorelasi secara positif dengan pengukuran alternatif dari konstruk yang sama. Suatu indikator dari variabel konstruk dikatakan valid atau tidak, dapat dilihat dari nilai outer loading. Jika nilai outer loading lebih besar dari (0.4) maka suatu indikator adalah valid. Kemudian validitas diskriminan dilakukan untuk menilai suatu indikator dari variabel konstruk adalah valid atau tidak, yakni dengan cara melihat Nilai Heterotrait - Monotrait Ratio Of Corelation $(\mathrm{HTMT})<0,90$, maka variabel memiliki validitas diskriminan yang baik (valid).

Analisis model struktural atau (inner model) dilakukan untuk menguji hipotesis penelitian. Bagian yang perlu dianalisis dalam model structural yakni, koefisien determinasi (R Square) dengan pengujian hipotesis. Koefisien determinasi (R Square) bertujuan untuk mengevaluasi keakuratan prediksi suatu variabel. Dengan kata lain untuk mengevaluasi bagaimana variasi nilai variabel terikat dipengaruhhi oleh variasi nilai variabel bebas pada sebuah model jalur.

Tabel 2. Koefisien Determinasi

\begin{tabular}{|c|c|c|}
\hline Variabel & R Square & Adjusted R Square \\
\hline Kepuasan Kerja (X4) & 0.559 & 0.542 \\
\hline Kinerja Pegawai (Y) & 0.750 & 0.737 \\
\hline
\end{tabular}

Sumber: Pengolahan Data PLS 3.0

Pada tabel 1.2 di atas diperoleh hasil koefisien determinasi bahwa R Square variabel gaya kepemimpinan, budaya organisasi, motivasi kerja dan kepuasan kerja terhadap kinerja pegawai adalah sebesar 0.750 artinya besaran pengaruh gaya kepemimpinan, budaya organisasi, motivasi kerja dan kepuasan kerja terhadap kinerja pegawai adalah sebesar $75.0 \%$ dan sisanya $25.0 \%$ dipengaruhi atau dijelasakan oleh faktor lain atau variabel yang tidak diteliti dalam model penelitian. Kemudian, gaya kepemimpinan, budaya organisasi dan motivasi kerja terhadap kepuasan kerja adalah sebesar 0.559 artinya besaran pengaruh gaya kepemimpinan, budaya organisasi dan motivasi kerja terhadap kepuasan kerja adalah sebesar $55.9 \%$ dan sisanya $45.1 \%$ dipengaruhi atau dijelaskan oleh faktor lain atau variabel yang tidak diteliti dalam model peneltian ini. 
Terdapat dua tahapan dalam pengujian hipotesis ini, yakni pengujian hipotesis pegaruh langsung dan pengujian hipotesis pengaruh tidak langsung melalui pengujian signifikansi koefisien jalur model structural (Structural Model Path Coeffisient). Pengujian ini dilakukan untuk menentukan koefisien jalur dari model structural, dan menguji signifikansi semua hubungan atau pengujian hipotesis. Adapun koefisien-koefisien jalur pengujian hipotesis terdapat pada gambar di bawah ini:

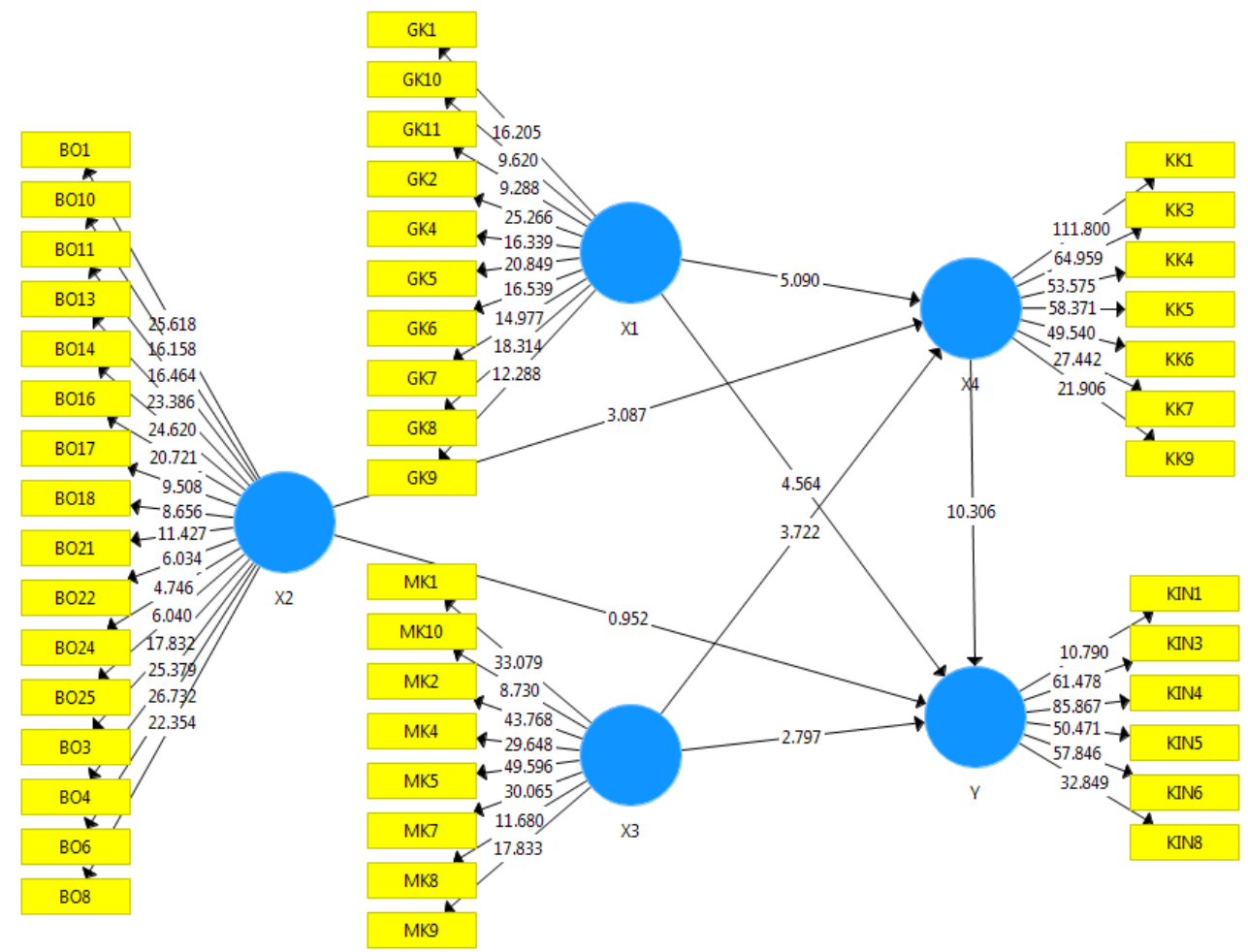

Gambar 2. Koefisien Jalur

Pengujian hipotesis pengaruh langsung bertujuan untuk membuktikan hipotesishipotesis pengaruh suatu variabel terhadap variabel lainnya secara langsung. Jika nilai koefisien jalur adalah positif mengindikasikan bahwa kenaikan nilai suatu variabel diikuti oleh kenaikan nilai variabel lainnya. Jika nilai koefisien jalur adalah negatif mengindikasikan bahwa kenaikan suatu variabel diikuti oleh penurunan nilai variabel lainnya. Jika nilai probabilitas (PValue) < Alpha (0.05) maka Ho ditolak (pengaruh suatu variabel dengan variabel lainnya adalah signifikan). Jika nilai probabilitas (P-Value) > Alpha (0.05) maka Ho ditolak (pengaruh suatu variabel dengan variabel lainnya adalah tidak signifikan).

Tabel 3. Hipotesis Pengaruh Langsung

\begin{tabular}{|c|c|c|c|c|c|}
\hline Matrix & $\begin{array}{c}\text { Original } \\
\text { Sample }\end{array}$ & $\begin{array}{c}\text { Sample } \\
\text { mean }\end{array}$ & $\begin{array}{c}\text { Standard } \\
\text { Deviation }\end{array}$ & $\begin{array}{c}\mathrm{T} \\
\text { Statistic }\end{array}$ & $\begin{array}{c}\mathrm{P} \\
\text { Values }\end{array}$ \\
\hline $\begin{array}{c}\text { Gaya Kepemimpinan -> } \\
\text { Kepuasan Kerja }\end{array}$ & 0.404 & 0.409 & 0.081 & 4.975 & 0.000 \\
\hline Gaya Kepemimpinan -> Kinerja & 0.286 & 0.294 & 0.062 & 4.582 & 0.000 \\
\hline
\end{tabular}


Muhammad Fais Fahmi, Cablullah Wibisono, Bambang Satriawan

\begin{tabular}{|c|c|c|c|c|c|}
\hline $\begin{array}{c}\text { Budaya Organisasi -> } \\
\text { Kepuasan Kerja }\end{array}$ & 0.274 & 0.273 & 0.093 & 2.932 & 0.003 \\
\hline Budaya Organisasi -> Kinerja & -0.064 & -0.069 & 0.067 & 0.944 & 0.456 \\
\hline Motivasi Kerja -> Kepuasan Kerja & 0.366 & 0.365 & 0.101 & 3.629 & 0.003 \\
\hline Motivasi Kerja -> Kinerja & -0.227 & -0.219 & 0.078 & 2.902 & 0.003 \\
\hline Kepuasan Kerja -> Kinerja & 0.811 & 0.803 & 0.085 & 9.522 & 0.000 \\
\hline
\end{tabular}

Sumber: Pengolahan Data PLS 3.0

\section{Pengaruh langsung variabel Gaya Kepemimpinan terhadap variabel Kepuasan Kerja}

Berdasarkan hasil analisis, ditemukan nilai koefisien jalur sebesar 0.404 (positif), sehingga adanya peningkatan nilai variabel gaya kepemimpinan akan diikuti tingginya kepuasan kerja. Pengaruh variabel gaya kepemimpinan terhadap kepuasan kerja memiliki nilai P-Values sebesar $0,000<0,05$, sehingga dapat dinyatakan bahwa ada pengaruh langsung signifikan antara gaya kepemimpinan dan kepuasan kerja. Hasil penelitian ini sesuai dengan teori yang di kemukakan oleh Asnawi (2011) kepemimpinan merupakan kemampuan untuk dapat mempengaruhi dan mengatur perilaku sendiri, seseorang, atau sekelompok orang untuk dapat mencapai tujuan tertentu. Menurut Thoha, (2010) gaya kepemimpinan ialah suatu aturan yang mengatur perilaku seseorang dalam mempengaruhi orang lain. Dengan kata lain gaya kepemimpinan para pemimpin yang sudah ada di kantor Badan Pengelolaan Keuangan dan Aset Daerah kota Tanjungpinang sudah sangat baik karena dapat mempengaruhi para pegawai untuk dapat melakukan pekerjaan tanda adanya tekanan dan paksaaan sehigga menciptakan kepuasan bagi para pegawai dalam bekerja. Hasil penelitian ini sama dengan yang di dapatkan oleh Brury (2016) dimana hasil penelitian menunjukkan bahwa terdapat pengaruh positif yang signifikan antara gaya kepemimpinan terhadap kepuasan kerja.

\section{Pengaruh langsung variabel Budaya Organisasi terhadap variabel Kepuasan Kerja}

Berdasarkan hasil analisis, ditemukan nilai koefisien jalur sebesar 0.274 (positif), maka adanya peningkatan nilai variabel budaya organisasi akan diikuti tingginya kepuasan kerja. Pengaruh variabel budaya organisasi terhadap kepuasan kerja memiliki nilai P-Values sebesar $0,000<0,05$, sehingga dapat dinyatakan bahwa ada pengaruh langsung signifikan dari budaya organisasi terhadap kepuasan kerja. Hasil penelitian ini sesuai dengan teori yang di kemukakan oleh Robbins dan Judge (2011) yang menegaskan bahwa budaya organisasi adalah sistem makna bersama yang diselenggarakan oleh anggota yang membedakan satu organisasi dengan organisasi lain, sehingga sistem budaya organisasi dapat menciptakan kepuasan kerja pada tiap individu para pegawai. Sistem organisasi atau budaya organisasi yang telah di terapkan oleh para Pegawai di kantor Badan Pengelolaan Keuangan dan Aset Daerah kota Tanjungpinang dalam meningkatkan kepuasan kerja tiap individu sudah sangat baik. Karena budaya organisasi yang baik dengan saling menghargai dan adanya kesetraaan dan orientasi awal yang baik dalam bekerja akan menciptakan keamanan dan kenyamanan bagi pegawai dalam bekerja sehingga kepauasn kerja tiap individu pegawai akan meningkat. Hasil ini mendukung penelitian yang dilakukan oleh Alvina \& Djastuti (2018) yang membuktikan bahwa budaya organisasi terbukti berpengaruh positif dan signifikan terhadap kepuasan kerja.

\section{Pengaruh langsung variabel Motivasi Kerja terhadap Kepuasan Kerja}

Berdasarkan hasil analisis, ditemukan koefisien jalur sebesar 0.366 (positif), hal ini berarti peningkatan nilai variabel motivasi kerja akan diikuti peningkatan variabel kepuasan kerja. Pengaruh variabel motivasi kerja terhadap kepuasan kerja memiliki nilai P-Values 
sebesar $0,003<0.05$, sehingga dapat dinyatakan bahwa ada pengaruh langsung positif signifikan antara motivasi kerja terhadap kepuasan kerja. Hasil penelitian ini sesuai dengan teori yang di kemukakan oleh Hasibuan (2014) yaitu motivasi adalah pemberian daya penggerak yang menciptakan kegairahan kerja seseorang, agar mereka mau bekerja sama, bekerja efektif dan terintegrasi dengan segala daya upayanya untuk mencapai kepuasan, sehingga pemberian motivasi akan sangat penting dilakukan supaya dapat merangsang kepuasan kerja para pegawai. Pemberian motivasi dapat dilakukan dengan memberikan penghargaan atas kinerja. Hasil penelitian ini sejalan dengan penelitian Lusri (2017) yang menemukan bahwa motivasi kerja terbukti berpengaruh positif dan signifikan terhadap kepuasan kerja.

\section{Pengaruh langsung variabel Gaya Kepemimpinan terhadap variabel Kinerja}

Berdasarkan hasil analisis, ditemukan nilai koefisien jalur sebesar 0.286 (positif), maka adanya peningkatan nilai variabel gaya kepemimpinan akan diikuti tingginya kinerja. Pengaruh gaya kepemimpinan terhadap kinerja memiliki nilai $\mathrm{P}$-Values sebesar $0,000<0,05$, sehingga dapat dinyatakan bahwa gaya kepemimpinan memberikan pengaruh langsung signifikan terhadap kinerja. Busro (2018) menyatakan bahwa gaya kepemimpinan adalah suatu cara bagaimana seorang pemimpin mampu memengaruhi para pengikut agar dengan sukrela mau melakukan berbagai tindakan bersama yang diperintahkan oleh pimpinan tanpa merasa bahwa dirinya ditekan dalam rangka mencapai tujuan organisasi. Berdasarakan hasil penelitian ini maka kantor Badan Pengelolaan Keuangan dan Aset Daerah kota Tanjungpinang gaya kepemimpinan yang di terapkan oleh para atasan sudah baik dan sangat mengayomi semua para pegawai sehingga para pegawai dapat mengingkatkan kinerjanya. Hasil penelitian ini sejalan dengan Wahyuni (2015) yang menemukan bahwa terdapat pengaruh positif yang signifikan antara varabel gaya kepemimpinan terhadap kinerja dengan nilai $\mathrm{R}$ square 0.364 atau $36.4 \%$.

\section{Pengaruh langsung variabel Budaya Organisasi terhadap variabel Kinerja}

Berdasarkan hasil analisis, ditemukan nilai koefisien jalur sebesar - 0.064 (negatif), artinya dengan adanya peningkatan nilai variabel Budaya Organisasi tidak secara langsung diikuti tingginya Kinerja. Pengaruh variabel Budaya Organisasi terhadap Kinerja memiliki nilai P-Values sebesar 0,456 >0,05, sehingga dapat dinyatakan bahwa tidak ada pengaruh langsung yang signifikan antara budaya organisasi dan kepuasan kerja. Penelaitian ini tidak sejalan dengan beberapa penelitian sebelumnya (Hajar, 2019; Effendy \& Fitria, 2017) yang menyatakan bahwa budaya organisasi mempengaruhi secara langsung dan sangat signifikan terhadap kinerja. Dalam Sebuah organisasi baik sektor pemerintah maupun swasta, budaya organisasi merupakan hal yang penting untuk meningkatkan kinerja dan mendorong produktivitas pegawai. Namun adanya nilai koefisien yang tidak signifikan secara langsung menunjukkan bahwa Pemerintah khususnya kantor Badan Pengelolaan Keuangan dan Aset Daerah kota Tanjungpinang masih sangat minim dalam menjalankan budaya organisasi yang baik. Selain dari pada itu masih terjadi adanya ketidaksesuaian antara aturan organisasi dan budaya yang dikembangkan terhadap pekerjaan yang dilakukan.

\section{Pengaruh langsung variabel Motivasi Kerja terhadap Kinerja}

Berdasarkan hasil analisis, ditemukan koefisien jalur sebesar -0.227 (negatif), artinya dengan adanya peningkatan nilai variabel Motivasi Kerja, maka tidak secara langsung akan 
diikuti kenaikan nilai Kinerja. Pengaruh variabel Motivasi Kerja terhadap Kinerja memiliki nilai P-Values sebesar $0,003<0,05$, sehingga dapat dinyatakan bahwa ada pengaruh langsung signifikan antara Motivasi Kerja terhadap Kinerja.

Hasibuan (2015) menyebutkan bahwa motivasi adalah pemberian daya gerak yang menciptakan kegairahan kerja seseorang, agar mereka mau bekerja sama secara produktif berhasil mencapai dan mewujudkan tujuan yang telah ditentukan. Sumber daya manusia atau pegawai membutuhkan stimulus berkelanjutan agar tetap bisa menjalankan tugas-tugasnya dengan baik dalam hal ini, motivasi kerja sangat dibutuhkan. Tanpa motivasi, seorang pegawai tidak akan merasa antusias menyelesaikan pekerjaannya dan juga mudah putus asa apabila mengalami kegagalan. Hasil penelitian ini menggambarkan bahwa motivasi kerja yang dirasakan oleh pegawai kantor Badan Pengelolaan Keuangan dan Aset Daerah kota Tanjungpinang sudah sangat baik yaitu dengan adanya penghargaan atas prestasi atau keberhasilan atas pekerjaan yang diraih, dihargai oleh atasan atau pimpinan apabila ada pekerjaan dengan memuaskan, diberikan kesempatan untuk mengembangkan diri serta mendapatkan kesempatan yang sama untuk mendapatkan kenaikan jabatan atau golongan. Hasil ini mendukung penelitian yang dilakukan oleh Adinata (2016) yang menemukan bahwa motivasi kerja terbukti berpengaruh positif dan signifikan terhadap kinerja pegawai secara simultan, yaitu sebesar $78 \%$.

\section{Pengaruh langsung variabel Kepusan Kerja terhadap variabel Kinerja Pegawai}

Berdasarkan hasil analisis, ditemukan koefisien jalur sebesar 0.811 (positif), artinya Kepuasan kerja Pegawai yang meningkat maka akan diikuti nilai variabel Kinerja Pegawai. Pengaruh variabel Kepuasan kerja terhadap variabel Kinerja Pegawai memiliki nilai P-Values sebesar $0,000<0,05$, sehingga dapat dinyatakan bahwa ada pengaruh langsung positif signifikan antara Kepuasan kerja terhadap Kinerja Pegawai.

Pegawai yang dapat memenuhi tuntutan lingkungan kerja disebut orang yang memuaskan yang dapat tercermin pada unjuk kerjanya, begitu pula sebaliknya orang yang tuntutannya terpenuhi oleh lingkungan kerja disebut orang yang puas akan kerjanya. Kepuasan kerja sangat erat kaitannya dengan situasi dan kondisi suatu organisasi tidak terkecuali di kantor Badan Pengelolaan Keuangan dan Aset Daerah kota Tanjungpinang. Apabila dalam suatu organisasi sesuai dengan harapan pegawai, maka akan menimbulkan suasana yang dapat menyenangkan pegawai, sehingga pengalaman individu di tempat kerja akan mewarnai sikapnya di luar lingkungan pekerjaan dan membawa kebahagiaan secara umum. Dapat disimpulkan bahwa pegawai merasa bahwa kepusan kerja yang mereka dapatkan selama ini dalam bekerja sangat berperan dalam memingkatkan kinerja. Hasil ini sejalan dengan penelitian Susanto (2019) yang menemukan bahwa kepuasan kerja terbukti berpengaruh positif dan signifikan terhadap Kinerja.

Pengujian hipotesis pengaruh tidak langsung bertujuan untuk membuktikan hipotesishipotesis pengaruh suatu variabel terhadap variabel lainnya secara tidak langsung (melalui perantara). Jika nilai korfisien pengaruh tidak langsung > koefisien pengaruh langsnug, maka variabel intervening bersifat memediasi hubungan antara satu variabel dengan variabel lainnya. Sebaliknya, Jika nilai korfisien pengaruh tidak langsung < koefisien pengaruh langsung, maka variabel intervening tidak bersifat memediasi hubungan antara satu variabel dengan variabel lainnya. 
INOBIS: Jurnal Inovasi Bisnis dan Manajemen Indonesia

Volume 04, Nomor 04, September 2021

Muhammad Fais Fahmi, Cablullah Wibisono, Bambang Satriawan

Tabel 4. Hipotesis Pengaruh Tidak Langsung

\begin{tabular}{|l|r|r|r|r|r|}
\hline \multicolumn{1}{|c|}{ Matrix } & $\begin{array}{c}\text { Original } \\
\text { Sample }\end{array}$ & $\begin{array}{c}\text { Sampel } \\
\text { Mean }\end{array}$ & $\begin{array}{c}\text { Standard } \\
\text { Deviation }\end{array}$ & $\begin{array}{c}\text { T } \\
\text { Statistic }\end{array}$ & $\begin{array}{c}\text { P } \\
\text { Values }\end{array}$ \\
\hline $\begin{array}{l}\text { Gaya Kepemimpinan -> Kepuasan } \\
\text { Kerja -> Kinerja }\end{array}$ & 0.328 & 0.327 & 0.064 & 5.050 & 0.00 \\
\hline $\begin{array}{l}\text { Budaya Organisasi -> } \\
\text { Kepuasan kerja-> Kinerja }\end{array}$ & 0.223 & 0.220 & 0.081 & 2.730 & 0.00 \\
\hline $\begin{array}{l}\text { Motivasi kerja-> } \\
\text { Kepuasan kerja -> Kinerja }\end{array}$ & 0.297 & 0.294 & 0.091 & 3.243 & 0.00 \\
\hline
\end{tabular}

Sumber: Pengolahan Data PLS 3.0

1. Berdasarkan tabel 1.4 diperoleh nilai $P$ Values pengaruh tidak langsung yakni variabel Gaya Kepemimpinan terhadap Kinerja Pegawai melalui Kepuasan Kerja sebesar 0,00 $<0,05$ artinya Pengaruh Gaya Kepemimpinan terhadap Kinerja Pegawai yang di mediasi oleh Kepuasan Kerja berpengaruh signifikan.

2. Berdasarkan tabel 1.4 diperoleh nilai $P$ Value pengaruh tidak langsung variabel Budaya Organisasi terhadap Kinerja pegawai melalui Kepuasan Kerja sebesar 0,00 $<0,05$ artinya. Pengaruh Budaya Organisasi terhadap Kinerja pegawai di mediasi oleh Kepuasan Kerja berpengaruh signifikan.

3. Berdasarkan tabel 1.4 diperoleh nilai $\mathrm{P}$ Value pengaruh tidak langsung variabel Motivasi kerja terhadap Kinerja Pegawai melalui Kepuasan Kerja sebesar 0,00 $<0,05$ artinya Pengaruh Motivasi kerja terhadap Kinerja pegawai yang di mediasi oleh KepuasanKerja berpengaruh signifikan.

\section{Kesimpulan}

Hasil temuan analisis data dalam pembahasan serta pengujian hipotesis, maka dapat disimpulkan bahwa Terdapat pengaruh langsung gaya kepemimpinan terhadap kepuasan kerja dengan nilai koefisien jalur positif, maka adanya peningkatan nilai variabel gaya kepemimpinan akan diikuti tingginya kepuasan kerja. Terdapat pengaruh langsung budaya organisasi terhadap kepuasan kerja dengan nilai koefisien jalur positif, maka adanya peningkatan nilai variabel budaya organisasi akan diikuti tingginya kepuasan kerja. Terdapat pengaruh langsung motivasi kerja terhadap kepuasan kerja dengan koefisien jalur positif, hal ini berarti peningkatan nilai variabel motivasi kerja akan diikuti peningkatan variabel kepuasan kerja. Terdapat pengaruh langsung gaya kepemimpinan terhadap kinerja dengan nilai koefisien jalur positif, maka adanya peningkatan nilai variabel gaya kepemimpinan akan diikuti tingginya kinerja. Tidak terdapat pengaruh langsung budaya organisasi terhadap kinerja dengan nilai koefisien jalur negatif, artinya dengan adanya peningkatan nilai variabel budaya organisasi tidak secara langsung diikuti tingginya kinerja. Terdapat pengaruh langsung motivasi kerja terhadap kinerja dengan koefisien jalur negatif, artinya dengan adanya peningkatan nilai variabel motivasi kerja, maka tidak secara langsung akan diikuti kenaikan nilai kinerja. Terdapat pengaruh langsung kepuasan kerja terhadap kinerja pegawai dengan koefisien jalur positif, artinya kepuasan kerja pegawai yang meningkat akan diikuti peningkatan kinerja pegawai. Terdapat pengaruh tidak langsung yang positif dari gaya 
kepemimpinan terhadap kinerja melalui kepuasan kerja. Terdapat pengaruh tidak langsung yang positif dari budaya organisasi terhadap kinerja melalui kepuasan kerja. Dan Terdapat pengaruh tidak langsung motivasi kerja terhadap kinerja melalui kepuasan kerja.

Koefisien determinasi bahwa (R Square) gaya kepemimpinan, komunikasi, motivasi kerja dan kepuasan kerja menjelaskan variabel kinerja lebih banyak dari pada sisanya dipengaruhi atau dijelasakan oleh faktor lain. Selanjutnya gaya kepemimpinan, komunikasi, dan motivasi kerja menjelaskan variabel kepuasan kerja lebih sedikit dari pada sisanya dipengaruhi atau dijelaskan oleh faktor lain atau variabel yang tidak diteliti dalam model peneltian ini.

\section{Daftar Pustaka}

Adinata, U. W. S. (2016). Pengaruh kepemimpinan motivasi, dan budaya transformasional, moorganisasi terhadap kinerja karyawan kjks bmt tamzis bandung. Jurnal Ekonomi, Bisnis \& Entrepreneurship, 9(2), 136-157.

Alvina \& Djastuti. (2018). Analisis Pengaruh Lingkungan Kerja Dan Budaya Organisasi Terhadap Komitmen Organisasional Dengan Kepuasan Kerja Sebagai Variabel Intervening (Studi Pada Karyawan Bagian Produksi Pt. Apac Inti Corpora, Bawen). Universitas Diponegoro, Manajemen, Fakultas Ekonomika dan Bisnis.

Annisa, A. (2013). Pengaruh employee engagement terhadap Kinerja Karyawan PT. Chandra Sakti Utama Leasing Jakarta. Universitas Indonesia.

Asnawi, T. (2011). Kepemimpinan. Jambi: Hamada Prima.

Bangun, W. (2012). Manajemen sumber daya manusia. Bandung : Penerbit Erlangga

Brury, M. (2016). Pengaruh Kepemimpinan, Budaya Organisasi, Motivasi Kerja Dan Kepuasan Kerja Terhadap Kinerja Pegawai Pada Kantor SAR Sorong. Jurnal Riset Bisnis dan Manajemen, Vol 4 , No.1, 1-16.

Busro, M. (2018). Teori-Teori Manajemen Sumber Daya Manusia. Jakarta: Prenadamedia Group.

Edy Sutrisno, 2014. Manajemen Sumber Daya Manusia. Cetak Ke Enam. Pranada Media Group, Jakarta

Emil dan Albetris, (2018). Pengaruh Gaya Kepemimpinan, Budaya Organisasi, dan Lingkungan Kerja Terhadap Kinerja Karyawan Melalui Motivasi pada PDAM Tirta Mayang Kota Jambi. Jurnal Manajemen dan Sains, 4(2), 437-451.

Effendy, A. A., \& Fitria (2017). Analisis Pengaruh Peran Kepemimpinan dan Budaya Organisasi terhadap Motivasi Kerja yang Berdampak pada Peningkatan Kinerja Karyawan (Studi Kasus PT. Putra Cita Nusa). Inovasi, 4(1).

Basna. (2016), Analisis Gaya Kepemimpinan, Kepuasan Kerja, Komitmen Organisasi dan Kompetensi Terhadap Kinerja Pegawai Badan Pendapatan Daerah Manado. Jurnal Riset Bisnis dan Manajemen. 4(3), 319.

Hersey, Paul dan Kenneth, H. Blanchard. Diterjemahkan Manguprawira, S. 2015."Kinerja Karyawan". Bandung: Alfabeta.

Hair, J., Hult, T., Ringle, C., \& Sarstedt, M. (2014). A Primer on Partial Least Squares Structural Equation Modeling (PLS-SEM). Thousand Oaks, CA: Sage Publications, Inc.

Hamidi, H. (2020). Pengaruh Gaya Kepemimpinan dan Motivasi Kerja terhadap Kinerja Karyawan. Jurnal Dimensi, 9(1), 1-16.

Hasibuan, M.S.P. (2012). Manajemen Sumber Daya Manusia Edisi Revisi. Jakarta: Bumi Aksara. 
Hasibuan, M. (2007). Manajemen Sumberdaya Manusia. Jakarta: Bumi Aksara.

Khasanah. (2013). Hubungan Antara Kepuasan Kerja Dengan Kinerja Karyawan Outsourcing Pt. Dwi Jaya Kota Pasuruan, 2 (27-28).

Malayu SP. Hasibuan, 2015, Manajemen Sumber Daya Manusia, Edisi Revisi. Jakarta : Bumi Aksara.

Marimin, A. (2011). Pengaruh Gaya Kepemimpinan, Motivasi Kerja dan Budaya Organisasi terhadap Kinerja Karyawan pada Bank Muamalat Indonesia Cabang Surakarta. Muqtasid: Jurnal Ekonomi dan Perbankan Syariah, 2(1), 23-37.

Prasada, D. (2020). Pengaruh Gaya Kepemimpinan dan Budaya Organisasi Terhadap Kinerja Karyawan Pada PT. Mandiri Konstruksi di Tangerang Selatan. Journal of Education, Humaniora and Social Sciences (JEHSS), 3(2), 629-636. DOI: https://doi.org/10.34007/jehss.v3i2.381

Prawirosentono, S. (2012). Kebijakan Kinerja Karyawan.Yogyakarta: BPFE.

Rivai Veithzal, 2011, Manajemen Sumber Daya Manusia untuk Perusahaan: dari Teori ke Praktik. Jakarta : Raja Grafindo Persada.

Robbins, S. P. \& Timothy. A. J. (2011). Organizational behavior. Fourteenth Edition. Pearson education. New Jersey 07458. 77-89

Schein, E.H. (2010). Organizational culture and leadership. San fransisco: Jossey bass.

Susanto, N. (2019). Pengaruh Motivasi Kerja, Kepuasan Kerja, dan Disiplin Kerja terhadap Kinerja Karyawan pada Divisi Penjualan Pt Rembaka. Agora, 7(1).

Susilo,. Leo, J. dan Kaho, V. R. (2018). Manajemen Risiko Berbasis ISO 31000:2018. Jakarta: Grasindo.

Thoha. (2010). Kepemimpinan dan Manajemen. Jakarta: PT. Raja Grafindo Persada, Jakarta.

Wahyuni, E. (2015). Pengaruh Budaya Organisasi Dan Gaya Kepemimpinan Terhadap Kinerja Pegawai Bagian Keuangan Organisasi Sektor Publik Dengan Motivasi Kerja Sebagai Variabel Intervening (Studi Kasus Pada Pegawai Pemerintah Kota Tasikmalaya). Nominal: Barometer Riset Akuntansi dan Manajemen, 4(1), 96-112. https://doi.org/10.21831/nominal.v4i1.6890

Widagho, D. (2010). Ilmu Budaya Dasar. Jakarta: Bumi Aksara.

Wibowo (2013). Manajemen Kinerja, Edisi Ketiga, Cetakan ke 7. Rajawali Pers Devisi Buku Perguruan Tinggi. Jakarta : PT. Raja Grafindo Persada. 